\title{
Stöttning av skrivande i ett digitalt diskussionsforum
}

\author{
Kan den digitala lärplattformens kursdesign utvecklas genrepedagogiskt?
}

\author{
Stina Hållsten* \\ Institutionen för kultur och lärande, Södertörns högskola
}

\begin{abstract}
Vi vet att studenter ofta upplever akademiskt skrivande som svårt. Att skrivandet dessutom förläggs till en digital lärplattform underlättar kanske inte alltid. Större studentgrupper och minskade resurser, parallellt med ett större utbud av distanskurser, gör att digitala lärplattformar blir än viktigare inom högre utbildning. Forskning visar dock att vi i första hand använder lärplattformar i administrativt syfte, trots möjligheter till en mer pedagogisk användning, exempelvis genom mer interaktion och ett större fokus på skrivandet. Hur kan lärplattformens design och användning utvecklas pedagogiskt, närmare bestämt med ett genrepedagogiskt upplägg?

Empirin för artikeln är en distanskurs i kriminologi, där all kursaktivitet skedde över utbildningens lärplattform. Kursdesignen och lärarnas aktivitet (instruktioner, responsgivande och annan stöttning) analyserades tillsammans med ett mindre antal studenters användande av lärplattformen i arbetet med uppgiften Lärandedialogen. Vilka genrepedagogiska drag uppvisas redan i kursdesignen, och vilka skulle kunna förstärkas? Genrepedagogiken tar fasta på den muntliga dialogen kring text och innehåll. Därför diskuteras även hur man kan se den skriftliga, asynkrona diskussionen som något liknande det muntliga seminariesamtalet.
\end{abstract}

Nyckelord: digital lärplattform, kursdesign, genrepedagogik, stöttning, akademiskt skrivande, register

\section{INLEDNING}

Svaret på frågan hur vi ska hantera allt större studentgrupper handlar många gånger om mer självstudier och ökat användande av digitala resurser, exempelvis lärplattformar ${ }^{1}$ (Rienecker \& Stray Jörgensen 2003). TEL-forskningen (Technology-enhanced learning) pekar dock tydligt på att pedagogiken inte är så utvecklad som den skulle kunna vara (Winters \& Mor 2009; se även Mörndahl 20II). En central fråga är därför hur pedagogiken kan utvecklas.

Den här artikeln undersöker hur en digital lärmiljö stöttar eller skulle kunna stötta studenter i deras lärande. Kan designen fungera som pedagogiskt stöd (och inte bara administrativt)? Ger designen läraren möjlighet att använda lärplattformen på ett pedagogiskt medvetet sätt?

Tidigare forskning visar att många parametrar måste "stämma" för att studenter och lärare ska använda plattformen på ett sätt som var tänkt (se Brown 2016 för en forskningsöversikt). Det verkar exempelvis vara så att motivationen att använda verktygen är avhängig av den återkoppling och respons studenter får (Fryer \& Bovee 20I6). Tsai \& Tsai (20I4) har undersökt skriv- och argumentationsstöd i form av inbyggda promter med nyckeformuleringar, med syfte att ge handfast stöd för argumentationsstruktur. Deras studie visar att detta inbyggda verktyg inte alltid gav den stöttning som man hoppats på. Studenter som inte erbjöds stödet strukturerade sina

\footnotetext{
* Författarkontakt: Stina Hållsten, stina.hallsten@sh.se

Artiklar og reflektioner är kollegialt granskade. Övriga bidragstyper granskas av redaktionen. Se www.hogreutbildning.se ISSN 2000-7558
}

(C)2017 Stina Hållsten. This is an Open Access article distributed under the terms of the Creative Commons Attribution-NonCommercial 4.0 International License (https://creativecommons.org/licenses/by-nc/4.0/), allowing third parties to share their work (copy, distribute, transmit) and to adapt it, under the condition that the authors are given credit, that the work is not used for commercial purposes, and that in the event of reuse or distribution, the terms of this license are made clear.

Citation: Stina Hållsten (2017) "Stöttning av skrivande i ett digitalt diskussionsforum», Högre utbildning 7, 13-28. http://dx.doi.org/10.23865/ hu.v7.904

1 Andra benämningar är Virtual Learning Platform, (VLE) Learning Management System (LME) eller Content Managing System (CMS). 


\section{S. Hållsten}

argumentationer trovärdigt på "fri hand" (Tsai \& Tsai 20I4:46). Undersökningen visar dock på en stöttningspotential som den digitala lärplattformen erbjuder. Hur kursdesignen faktiskt kommer att användas av studenter och lärare kan vi dock inte veta innan vi undersöker även användandet: "Notably, there is one thing what the design of the $\mathrm{VLE}^{2}$ aims for, another what will happen when teachers and students start using the VLE" (Hort et al. 2016:2). Vi behöver därmed mer empirisk forskning om hur studenter tar sig an sina studier över en lärplattform: vilka redskap som erbjuds och hur de används.

WIDE-projektet ${ }^{3}$ visar att tekniken i sig är et av flera potentiella hinder. Lika mycket vållar den akademiska kontexten, som förstås är ny för nybörjarstudenten, och det akademiska skrivandet bekymmer (Blåsjö et al. 20I4).

Undersökningar visar att studenters möte med utbildningens texter och skrivande, trots stöd (studieverkstäder, handledning, kurser i akademiskt skrivande) många gånger upplevs som svårt (Ask 2005, Blåsjö 2004), med ett stort hopp från ett tidigare utbildningsstadium till ett nytt. Det handlar inte bara om att lära sig ett nytt ämne, utan även om att lära sig att skriva inom en ny kontext med nya villkor. Flera studier tar också fasta på att tillägnande av ämneskunskaper även handlar om tillägnandet av ett språkligt register (af Geijerstam 2006, Nygård 20II): ett synsätt som innebär att ämnets språk och textanvändning är nära sammankopplat med själva ämnesinnehållet.

Hur skulle den digitala lärmiljön kunna utvecklas för att stötta studenters skrivande och lärande? Ett exempel på en pedagogisk modell för språkutveckling och lärande, som bygger på ovan nämnda synsätt och som fătt spridning i svenska klassrum, är genrepedagogiken (se Olofsson 2010 för en översikt).

Artikeln presenterar en fallstudie av arbetet med en skriftlig uppgift inom ämnet kriminologi som designas och genomförs, av lärare och studenter. Utifrån en genrepedagogisk modell för textanvändning och lärande har lärplattform, kursupplägg och skrivande analyserats, i första hand vad gäller kursdesignens och lärarens eventuella stöttning genom skrivarbetet.

Valet av genrepedagogik, som vilar dels på Vygotskijs (200I) teori om relation mellan språk och lärande, dels på Hallidays (1994) systemisk-funktionella lingvistik, grundar sig i flera undersökningar som visar på den potential pedagogiken har för att utveckla elever och studenter språkligt. Genrepedagogiken (Martin \& Rose 2008, Olofsson 20IO) kan sägas fånga kopplingen mellan språk och ämnesinnehåll och erbjuder en handfast metod för språkutvecklande arbete i klassrummet, med stort fokus på olika typer av stöttning (Vygotskij 200I, Gibbons 2006). Blåsjö, Knutsson \& Cerratto Pargman (2012) argumenterar för att genrepedagogiken skulle kunna användas som pedagogisk ram i lärplattformsdesignen, eftersom pedagogiken inbegriper tydliga kriterier för olika pedagogiska steg mot tillägnandet av såväl ämnesinnehåll som ämnets språk. Detta skulle passa högre utbildning, som många gånger baseras på skrivande och läsande av akademisk text.

Det finns dock få genrepedagogiska undersökningar applicerade på digitala lärplattformar. I en mindre studie analyserar Hort, Knutsson \& Blåsjö (2016) klassrumsaktiviteterna i tre australiensiska klassrum som använder genrepedagogik och diskuterar hur uppläggen skulle kunna inspirera designen av en lärplattform. Bland annat föreslås designmönster ("design patterns"), som exempelvis verktyg för kollaborativ brainstormning med syfte att bygga upp en gemensam kunskapsbas, samt konstruktion av en textkorpus med modelltexter för deltagarna att använda som

2 VLE=virtual learning environment

3 WIDE=Writing to Learn in a Digital Environment (2010-2012). Se Blåsjö et al. (2014), Knutsson et al. (2012). 
förebilder för sitt eget skrivande. Man föreslår också redskap för samskrivande, för att möjliggöra ett gemensamt byggande av texter (se nedan; det tredje steget i den genrepedagogiska modellen).

Denna studie har en pedagogisk ansats för att undersöka potentialen i att använda sig av ett genrepedagogiskt kursupplägg även i ett digitalt medium. Utgångspunkten är att all kommunikation mellan studenter och lärare är skriftlig. Mer specifikt undersöks både hur kursen var designad och hur lärplattformen användes av såväl lärare och studenter på kursen. Fokus ligger på vilken stöttning, något som är centralt för genrepedagogiken (Holmberg 20IO), som erbjöds $i$ kursdesign och instruktioner, och hur studenter gjorde när de löste en uppgift. Undersökningen inbegriper också själva skrivförloppet för några av kursens deltagare. Tidigare studier av skrivande har, såsom Holmberg (2013) påpekar, studerat texttillblivelse och skrivande i snäv mening, i bemärkelsen att man inte tagit hänsyn till kontexten kring själva skrivandet och det textorienterade samtalen. Man har alltså betonat "textstruktur på bekostnad av kontexten utanför texten." (Holmberg 20I3:69). Även Hyland (2004) argumenterar för vikten av att studera även den kontext texten producerats i. Genom att försöka synliggöra kontexten för skrivandet, i form av instruktioner, tekniska möjligheter och begränsningar och skribenternas egna beskrivningar av hur de arbetat, kommer vi att kunna säga mer om vilken roll det tekniska redskapet har för skrivandet.

Den genrepedagogiska modellen bygger till stor del på skrivande och skrivutveckling genom muntlig dialog. Mot bakgrund av detta diskuteras avslutningsvis möjligheten att se den skriftliga digitala diskussionen som en motsvarighet till det muntliga seminariet (Olofsson 2010:256, Holmberg 20IO:23-24). Detta sammantaget kan alltså fungera som utgångspunkt för hur användandet av lärplattformen kan utvecklas pedagogiskt.

\section{Teoretiska utgaingspunkter}

Genrepedagogiken vilar teoretiskt dels på en sociokulturell syn på lärande, dels på den systemiskfunktionella lingvistiken, SFL. SFL är en språkteori som tar fasta på relationen mellan språk och verklighet, där språket ses som en betydelsepotential från vilket vi gör språkliga val. Dessa val begränsas av det språkliga register inom vilket den aktuella kommunikationen äger rum, exempelvis ett vetenskapligt, vardagligt eller massmedialt register (Halliday 1978, Halliday \& Matthiessen 2004, Macken-Horarik 1996). För att kunna delta i exempelvis en arbetsgemenskap eller förstå en text måste man ha tillgång till det aktuella språkliga registret.

Även Vygotskijs (200I) sociokulturella teori om relationen mellan tänkande och lärande är central. Tanken att lärande sker i ett socialt sammanhang, där exempelvis läraren stöttar sina elever språkligt, genomsyrar det arbetssätt genrepedagogiken förespråkar. Ekholm (20I2) beskriver stöttning som erbjudande av en struktur vad gäller mål och syfte för exempelvis ett skrivarbete. I min undersökning kan det tolkas som lärarens instruktioner såväl som lärarrespons med fokus på den bedömda textens funktion och disposition. Gibbons ser stöttningen som en tillfällig hjälp som leder eleven, eller i det här fallet studenten, vidare mot nya färdigheter och nya nivåer av förståelse (Gibbons 2006). Det kan gälla såväl tillägnande av nya språkliga begrepp som behärskande av en ny språklig genre ${ }^{4}$. Varje genre innefattas av ett eller flera genresteg, som i sin tur kan analyseras med avseende på olika språkliga kategorier (Martin \& Rose 20I2:I28, Holmberg 20IO:I6ff).

Genom att explicitgöra språkliga krav och kriterier för olika språkliga aktiviteter och typiska texter inom respektive ämne synliggörs både kunskapsinnehållet och språkanvändningen inom ämnet.

4 Genre ses här som en målinriktad, social steg-för-stegaktivitet som enskilt eller tillsammans med andra genrer kan bilda en text. Exempel på genrer är argumentera, instruera, berätta. 


\section{S. Hållsten}

Det påverkar både förståelsen för ämnesinnehåll och förståelsen för (och behärskning av) den textanvändning, både skrivande och läsande, som ingår. En viktig del i pedagogiken är att identifiera typiska texter eller måltexter (Christie \& Unsworh 2005:7) inom ett speciellt kunskapsfält, för att explicitgöra de språkliga krav som ställs för att kunna läsa och skriva inom området.

Ett vanligt pedagogiskt förlopp går till så att lärare och studenter skapar en gemensam förståelse för ämnet, genom att bland annat dekonstruera för ämnet centrala texter, för att sedan gemensamt skriva texter och slutligen skriva individuellt (White 2009:55-56). På så sätt synliggörs genrespecifika och språkliga krav. Stor vikt läggs vid en aktivitet kallad 'building field' (ungefär 'bygga kunskapsfältet'). Genom att samtala om typiska texter utifrån SFL-terminologin skapar läraren och studenterna en gemensam kunskapsbas om såväl texter och språkanvändning inom ämnet som själva innehållet. Lärarens stöttande funktion är central (Holmberg 20IO:23, Bergman \& Olsson 20I4:45, Gibbons 2006; se även Vygotskij 200I). Samtidigt kan andra än läraren fungera stöttande, exempelvis andra deltagare i gruppen.

Inom genrepedagogiken kan stöttning handla om att identifiera och namnge språkliga särdrag. Hur används begrepp och specifika fackord? Hur är texterna strukturerade? Vilka texter är centrala inom fältet? (Holmberg 20IO, Holmberg \& Wirdenäs 20IO). Stöttning skulle alltså kunna ses som både allmän, i form av allmänna stödstrukturer såsom kursbeskrivningar, instruktioner, tillfällen till dialog med lärare eller lärarens respons, som specifik, kopplad till en specifik pedagogisk modell eller de specifika uppgifterna som studenterna ska lösa. I artikelns avslutande diskussion kommer denna fråga att behandlas.

\section{Metod och material}

Kursen som undersöktes var en distanskurs i kriminologi vid ett svenskt universitet. Följande material ingick i studien:

- Lärplattformens gränssnitt och kurshemsida

- Allmän instruktion till lärandedialogerna

- Instruktion till lärandedialog 4.I.

- Lärandedialog 4.I (I4 inlägg skrivna av 9 studenter, 303I ord)

- Lärarrepons på lärandedialog 4.I om brottsförebyggande åtgärder (2668 ord)

- Enkät om arbetet på lärplattformen (23 insamlade enkäter)

- Student Marias datorlogg och loggbok

Det empiriska materialet består dels av den digitala plattformen och dess funktioner, dels texter lärare och studenter skrivit. Till materialet hör också enkätsvar om hur studenterna arbetat med en specifik uppgift. Närstudien av studenten Marias loggbok över arbetet respektive datorlogg ger en bild av hur lärplattformens erbjudna resurser användes. Textmaterialet samlades in i april och maj 2013. Enkäten delades ut till samtliga deltagare den aktuella kursomgången, och samlades in i december 2012.

Materialet är valt utifrån en etnografisk ansats (Flowerdew 2002), där deltagarperspektivet och syftet att undersöka en verksamhet i dess autentiska miljö eftersträvas. Inom digital etnografi är exempelvis deltagarnas egna loggböcker, videodagböcker etc. en vanlig materialtyp (Pink, Horst, Postill, Hjorth, Lewis \& Tacchi 20I5:46-49). I detta fall rör det sig om det digitala gränssnittet som sådant, deltagarnas egen uppfattning om deras arbete i denna digitala miljö, samt data från det faktiska arbetet i gränssnittet och den omgivande digitala kontexten. 
Genom en analys av själva gränssnittet och sammanställning av enkätsvaren från studenter, undersöks vilka resurser för stöttning som erbjöds och vilka som användes. Analysen av gränssnittet fokuserar på vilka funktioner som fanns tillgängliga och vilka som användes, samt vilken metafor gränssnittet vilade på (Blåsjö et al. 2012). Analysen av det som kan betraktas som stöttningsresurser fokuserar på vad som kan ses som allmän stöttning, för att delta i akademiska studier eller för skrivande generellt, och mer specifik stöttning inom ramen för det specifika kursupplägget.

Exempel på stöttningsresurser har varit såväl gränssnittets funktioner som lärarproducerade instruktionstexter. Lärarrespons har setts som en självklar resurs, så även olika instruerande texter som fokuserar på hur någon uppgift ska lösas. Dessutom har även litteraturläsning och läsning av andra studenters diskussionsinlägg betraktats som resurser för stöttning, men bara när studenten i sitt enkätsvar lyft fram detta som en resurs. Huruvida stöttningsresurserna kan ses som allmänna eller på olika sätt specifika diskuteras i artikels avslutande diskussionsavsnitt.

Vidare undersöks hur ett antal studenter tog stöttningen till vara. Metoden för detta är att genom enkäter, loggning av datoranvändning och insamlandet av en loggbok analysera deltagarnas användning av stöttningsresurserna.

Slutligen görs en analys av vilka genrepedagogiska inslag kursupplägget som helhet hade, vilka moment som skulle kunna förstärkas pedagogiskt och i så fall hur. Analysen bygger på det insamlade materialet och systematisering av detta utifrån en genrepedagogisk modell (Martin \& Rose 20I2, Holmberg \& Wirdenäs 20Io), där de genrepedagogiska stegen och den inbyggda stöttningen beaktas särskilt.

\section{Det empiriska materialet}

Den undersökta kursen var en distanskurs på grundnivå i ämnet kriminologi. All interaktion mellan lärare och studenter ägde rum över lärplattformen, via skrift.

Lärplattformens gränsnitt (fig. I) erbjöd en "kurshemsida" där vänsterspalten innehöll ett antal olika redskap (blogg, diskussionforum, mejlfunktion, inlämningslådor för olika uppgifter etc.). I högerspalten kunde man följa kursens chattforum och se de senaste nyheterna. Kursens design var delvis på förhand bestämd av själva systemet, delvis utformat av läraren i samråd med universitetets stödfunktioner för IT. Det fanns exempelvis möjlighet som lärare att välja och välja bort vissa redskap i vänsterspalten.

Kriminologikursens var indelad i fyra delkurser med likartat upplägg: studenterna läste litteraturen, skrev och läste olika diskussionsuppgifter, som de sedan sammanfattade, och skrev slutligen hemtentamen. Diskussionsuppgifterna var av två slag, studiebloggen och lärandedialogen. ${ }^{5}$

Studenterna arbetade i mindre grupper om 5-I2 deltagare. Uppgifter och kursmaterial fanns samlande i lärplattformen. Den allra första uppgiften på kursen syftade till att lära sig att använda plattformen, men efter detta var alla uppgifter inriktade på själva ämnesinnehållet, dvs. kriminologi. Det ställdes relativt höga krav på studenterna att delta aktivt, dvs. skriva, redan från första veckan. Vissa avhopp förklarades med att det var för högt tempo och höga krav just vad gäller skrivandet (Hållsten 20I3).

Lärandedialogen: Skrivuppgiften Lärandedialog var alltså en återkommande uppgift: varje delkurs innefattade 3-4 lärandedialoger, som skrevs i ett diskussionsforum. Läraren presenterade en frågeställning relaterad till den aktuella kurslitteraturen (ex. 3). Minimikravet var sedan att 


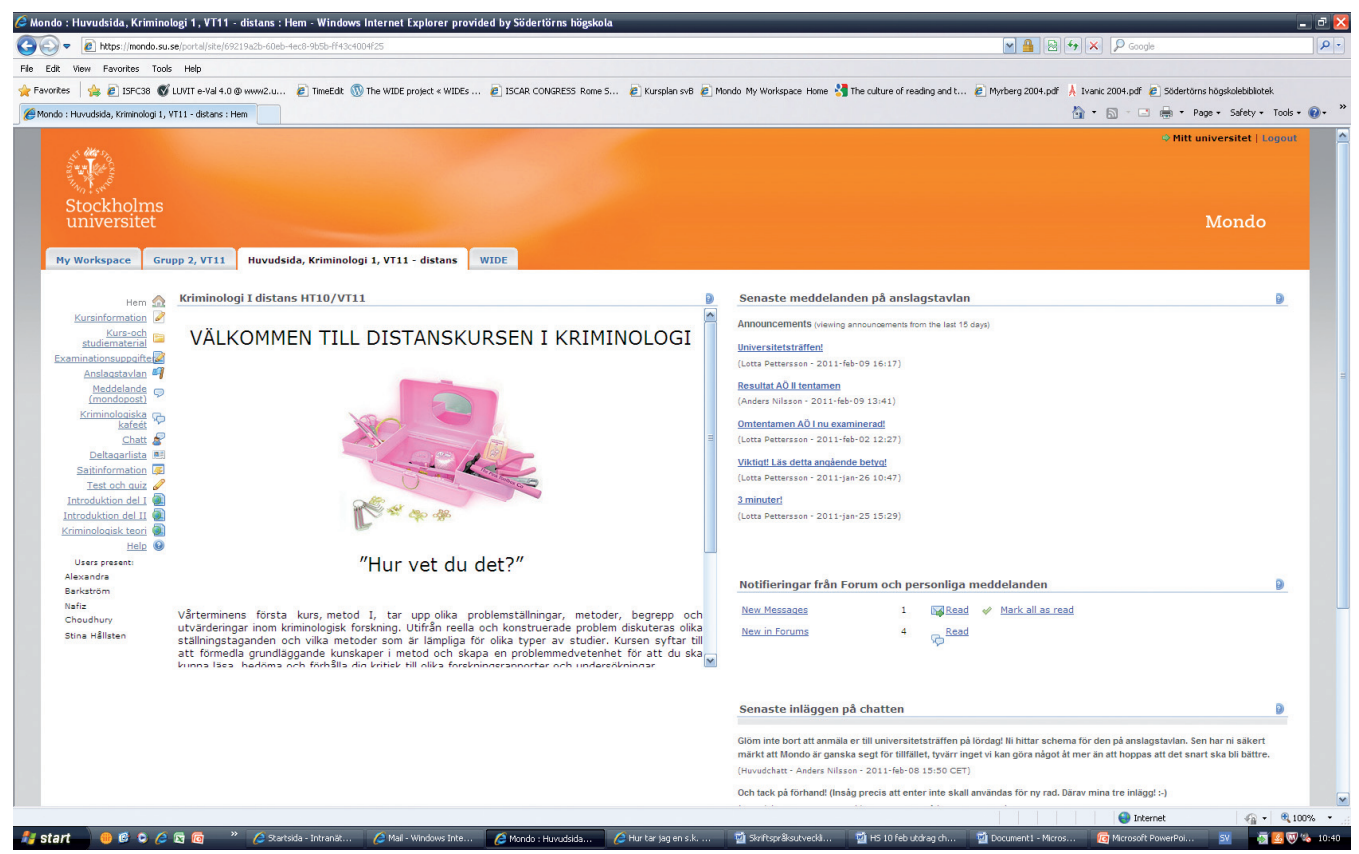

Fig 1. Lärplattformens gränssnitt

skriva minst två diskussionsinlägg; antingen starta en ny diskussion och sedan delta i den, eller svara på en redan startad diskussion. Varje deltagare sammanfattade slutligen dialogen i en individuell text, och postade den i en inlämningslåda. När lärandedialogen var slut fick gruppen en gemensam skriftlig respons av läraren. Efter delkursens lärandedialoger skrevs sedan hemtentamen.

I lärandedialogen ingick att diskutera givna frågor utifrån litteraturen och referera enligt gängse akademiska konventioner. Lärare på kursen såg detta som ett sätt att uppmuntra deltagarna att aktivt läsa litteraturen, och genom att skriva om det lästa och diskutera med andra bättre lära sig ämnet än om var och en enbart läste litteraturen.

\section{Resultat}

Vilken stöttning erbjöds studenterna under arbetet med lärandedialogen? Hur togs denna stöttning tillvara? Hur sågs arbetet ut för en enskild student, vad gäller planering och genomförande av skrivuppgiften och tillvaratagande av stöttningsresurser?

Vilken stöttning fick studenterna under skrivarbetet?: Ett centralt inslag i genrepedagogiken är lärarens stöttning genom hela skriv- och lärandeprocessen. Ett viktigt inslag är klassrumssamtalet (Holmberg \& Wirdenäs 2OIO:IIO-III).

Distanskursen hade inget fysiskt klassrum. Lärplattformen användes heller inte för att kommunicera muntligt ${ }^{6}$. Det stöd som i stället erbjöds var en allmän uppgiftsinstruktion och en specifik instruktion till den aktuella uppgiften. Dessutom kunde texter om vetenskapligt förhållningssätt, syftet med att referera till källor etc., fungera som stöd.

6 Det är möjligt att ordna samtal via webben eller på annat sätt, på distans, exempelvis via skype eller andra programvaror. Detta är dock inte något som gjordes på kursen. 
Deltagarna fick relativt mycket skriftligt stöd av lärarna. De kunde också på olika sätt kommunicera med lärarna kring ämnesinnehåll, uppgifter och respons, via olika chattforum och mejlfunktioner. De kunde även kommunicera med varandra, exempelvis via chattfunktioner.

En typ av stöttning var själva instruktionen till uppgifterna (I), i bemärkelsen att de pekade ut och därmed gav stöd kring vad studenterna förväntades göra och vilket material som skulle användas. Man förankrade också instruktionen ämnesmässigt:

(I) "Uppgiften består av en lärandedialog. Mellan den 2 maj och Io maj skall ni i grupperna ha en dialog kring brottsförebyggande arbete. Det skall ske i de forum som är publicerade för detta ändamål. Under perioden skall du, för att bli godkänd, ha skrivit minst två inlägg som relaterar till kursmålen, kursinnehållet och till övriga inlägg / . . / När diskussionen är avslutad skall du kort redogöra för dina centrala slutsatser i relation till frågorna / . . / Det går bra att publicera detta /.../ Vi kommer att läsa samtliga inlägg och ge feedback gruppvis.”

I uppgiftsinstruktionen (I) fokuserades delvis på vad som skulle göras i texten, genom olika aktiviteter riktade mot syftet med dialogen (redogöra för slutsatser, reflektera, relatera [innehållsligt] till kursmålen) och mot själva tekniken att göra detta (publicera). Den innehållsliga förankringen låg dels i ämnesrelaterade ord och begrepp (brottsförebyggande arbete), men även begrepp relaterade till utbildningens struktur (kursmål, kursinnehåll, övriga inlägg). Deltagarna fick också veta att lärarna skulle ge feedback. Slutligen fick deltagarna också instruktioner förankrat i själva uppgiftsterminologin: man skulle skriva inlägg, [ha] diskussion och [ha] dialog.

En annan stöttningsresurs var de orienterande texterna kring skrivande i ett diskussionsforum, där förståelse för eventuella svårigheter med att skriva "inför andra" synliggjordes (2):

(2) Ur "Syfte med kursen"

Vi är också medvetna om att vissa kan uppleva det som nervöst att publicera sina tankar i en text som alla andra kursdeltagare kan läsa. Det uttryckta kan upplevas som mer definitivt jämfört med att till exempel delta i en muntlig diskussion i ett klassrum.

Exempel 2 kan ses som en allmän stöttning till att alls skriva tillsammans med andra. Fokus låg på upplevd obekvämlighet i att skriva inför personer man inte känner, vilket lärarna i studien var medvetna om finns.

Med varje lärandedialog följde också en specifik instruktion (3):

(3) Lärandedialog 4.I

”...Mötesdeltagarna vänder sig till er för råd när de får veta att ni är insatta i litteraturen om brottsprevention. Vad bör de göra? Vad föreslår ni mötesdeltagarna? Exempelvis: Om ni utgår ifrån beskrivningen av problemet, vilka åtgärder skulle ni föreslå? / . . / Relatera till teorier om orsaker till brott och utvärderingar av olika åtgärder. Vilka aktörer skulle ni föreslå att de inkluderar i det brottsförebyggande arbetet? /.../ Resonera i så fall kring konsekvenserna av bristen på information? /.../

Litteraturen är den som täcker delmoment $\mathrm{I}-3$.

På Brottsförebyggande rådets hemsida hittar ni exempel på lokalt förebyggande, kanske kan det vara en inspiration för er diskussion? http://www.bra.se/bra/forebygga-brott.html";

Instruktionen till lärandedialog 4.I (3) presenterade en frågeställning deltagarna skulle diskutera på olika sätt. I instruktionen användes ämnesspecifika ord och uttryck (Brottsförebyggande rådet, 
brottsförebyggande arbete, teorier om orsaker till brott). Det fanns också, liksom i den allmänna instruktionen (I), verbkonstruktioner som angav vad det var för aktiviteter som efterfrågades (resonera, föreslå àtgärder, [föra] diskussion). Slutligen fanns explicita hänvisningar till kurslitteratur och andra användbara källor.

Ytterligare en stöttningsresurs var den lärarrespons grupperna fick efter avslutad dialog (4):

(4) Hej grupp 2 !

Tack för intressant läsning av den första lärandedialogen i kriminalpolitik. Överlag är era gruppdiskussioner välutvecklade, och ni för kritiska diskussioner där ni ofta lyckas integrera kunskap från tidigare moment i utbildningen! Inte minst märks det i hur ni i grupperna diskuterar olika kriminologiska teorier som förklaringsmodell t.ex. för ungdomarnas beteenden som beskrivs av initiativtagarna till diskussionen (sociala band, t.ex.) eller som utgångspunkt för att utforma förebyggande åtgärder (t.ex. rutinaktivitetsteorin).”

I lärarresponsen (4) uppmärksammades bland annat att deltagarna diskuterade, förde kritiska diskussioner och startade diskussion, vilket också var syftet med uppgiften (3). Dessutom uppmärksammades själva ämnesförankringen (hur ni i gruppen diskuterar olika kriminologiska teorier...).

Sammanfattningsvis kan sägas att kursdesign och instruktioner erbjöd stöttning på olika nivåer. Exempelvis fick studenterna stöttning i form av lärarrespons som vad gällde vilka språkliga aktiviteter man förväntades genomföra och vad gäller själva ämnesinnehållet. I responsen sades exempelvis inte bara att deltagarna diskuterade teorier utan det exemplifierades också hur detta gjordes.

Hur användes den erbjudna stöttningen?: Som visats i avsnittet ovan erbjöd kursdesignen olika möjligheter till stöttning och dialog (chattforum, mejl etc.) och stöttning i form av lärarnas egna instruktioner och responstexter ( $\mathrm{I}-4)$. Vilken stöttning använde deltagarna när de deltog i dialogen? Hur?

I den enkät jag skickade ut ombads deltagarna ge detaljerade beskrivningar av hur de arbetade med skrivandet. Ett relativt långt svar löd:

(5) (enkätsvar I. I2I2I8) ” Missade den första lärandedialogen så den gjorde jag komplettering på. Den andra och tredje dialogen jag deltog i så var jag den som startade dialogen, första eller andra dagen som den var öppen. Den litteratur som var relevant läste jag in för att dialogen startade och återgick till den om jag behövde under dialogens gång. När jag väl gjort inlägg så väntade jag tills andra skrivit inlägg för att då sätta mig och läsa allas inlägg och kommentera, gärna om jag kunde knyta an till fleras inlägg i en kommentar. Jag avsätter tid för varje inlägg specifikt för de olika uppgifterna, det sker sällan spontant. Upplevde att det under dialog 2 och 3 på AÖI var svårt att föra en dialog då flera verkade ha hoppat av kursen, eller inte hade möjlighet att delta i just det momentet. Det gjorde att vi under en dialog endast var två deltagare. Då kände /..."”

I (5) kan litteraturen tolkas som en resurs, tillsammans med övriga gruppmedlemmars inlägg. Rimligen lästes även instruktionen (3), men det är inget som studenten själv nämnde. I svaret beskrevs en växling mellan att läsa litteratur och att skriva inlägg, och studenten behövde också förhålla sig till själva uppgiftsdesignen - det krävdes en del väntan och pauser för att kunna skriva vidare och slutföra diskussionsuppgiften. Lärarresponsen (från exempelvis tidigare uppgifter) togs inte upp, däremot kursinformation och andra studenters inlägg. 
En enkätfråga löd: Skulle du behöva eller vilja ha annat stöd inför hemtentan? Vad i så fall?

(6) (enkätsvar 2. I2I208) Nej, inte som jag kan komma på. Tycker att lärandedialogerna och bloggarna är ett bra sätt att underlätta inför hemtentan. Vi har då hunnit bearbeta i princip all litteratur och reflekterat över den, vilket jag tycker varit ett väldigt bra sätt för att förbereda hemtentan.

Hemtentamen var det sista skriftliga momentet på varje delkurs, och texterna som skrivits under kursens gång, tillsammans med lärarens respons på de olika uppgifterna, skulle kunna användas som stöttning för arbetet med hemtentan. I (6) visar studenten att hen anammat lärarnas idé bakom kursdesignen vad gäller sambandet mellan de olika skriftliga momenten - lärarna har mycket riktigt lyft fram tanken med att skriva olika texter, sammanfatta dessa och på så sätt aktivt sätta sig in i kurslitteraturen och därmed lära sig ämnet.

Närstudie av Marias arbete med lärandedialog 4.I: För att få en fördjupad bild av hur arbetet med en lärandedialog kunde gå till, och hur den erbjudna stöttningen eventuellt togs tillvara, följer här en presentation av hur studenten Maria beskriver sitt arbete. Som komplement till Marias egen beskrivning finns hennes datorlogg som visar hur datorn använts i arbetet med dialogen.

Maria har på eget initiativ dirigerat om alla inlägg i Lärandedialogen till sitt mejlprogram, för att kunna följa vad som händer utan att behöva logga in och använda plattformen. I (7) och (8) beskrivs hur Maria startade sitt arbete med lärandedialogen och publicerade sitt första inlägg.

(7) 26 April 2013

Kollar nyheter och antagning.se

Läser 9.30-II

Planerar framtida studier, kollar kurser på antagning.se m.m.

Läser I2.30-13.30

Lunch

Läser 15-15.20 Får telefonsamtal

Läser 15.45-I6.40 Loggar in på [lärplattformen] för att kolla frågorna till Lärandedialog 4.I,

kollar antagning.se, Handels, får telefonsamtal

Läser $17.30-18.30$

Läser 19.30-2I

(8) Loggbok $2 / 5$

Kollar nyheter.

Läser igenom inlägg I och gör små justeringar, loggar in på [lärplattformen] och lägger upp mitt inlägg samt läser det som lagts upp redan (bara ett annat än så länge).

Tränar.

Pluggar annat.

Publicerar det på [lärplattformen].

Pluggar sedan annat resten av dagen samt $7 / 5$.

Loggboken (7-8) visar att Maria arbetade med flera saker parallellt. Hon inledde dock själva dialogarbetet med att läsa litteraturen, och började skriva först ett par dagar in i processen. 
Den 30 april (7) skrev Maria på det första inlägget, och den 2 maj (8) gjorde hon små justeringar och la upp inlägget på kurswebben. Hon nämner dock inte att hon aktualiserat lärarrespons från någon tidigare uppgift som förberedelse för arbetet med den nya.

I Lärandedialogen såg det sedan ut så här (9):

(9) Marias inlägg I (nr 2 i tråden)

"... Oavsett verkar området behöva öka den sociala kontrollen och sammanhållningen, precis som [Ulla] skriver, för att minska invånarnas misstänksamhet mot varandra, vilket kan ske genom t.ex. grannsamverkan (Sarnecki, 2009, s. 496). /.../"

I Marias inlägg I (9) kan man läsa "...precis som [Ulla] skriver..”. Sådana drag fanns även i andra studenters inlägg i lärandedialogen (Lärandedialog 4.I.) Dessa referenser till andra studenter kan förklaras med att det fanns explicita krav på att inläggen skulle relateras inte bara till kurslitteraturen utan även till andras inlägg (2). Det kan också ses som att Maria (och de andra) såg inläggen som ett slags diskussion, där man kopplar sin "replik" till föregående talare / skribent.

Marias andra inlägg, som hon alltså påbörjat innan någon annan student deltagit i diskussionen, innehöll inte några sådana drag av dialog, utan var snarare en innehållslig utveckling av det egna första inlägget. Det som kan betraktas som stöttning, dvs. andra studenters diskussionsinlägg, användes inte.

(Io) Marias inlägg 2 (nr 6 i tråden)

"För att få information om brottsnivåerna kan man använda sig av brottsstatistiken över anmälda brott i området, men..."

Det kan tolkas som att Maria denna gång alltså inte verkade vara inställd på att diskutera med de andra deltagarna. Hon kommenterade själv att hon planerat sin tid annorlunda denna gång jämfört med tidigare uppgifter (II).

(II) Ur Marias loggbok

Har redan läst det mesta inför Studieblogg 4.I, därför blir det betydligt mycket mindre lästid än vanligt inför den här Lärandedialogen. Därför har jag också hunnit skriva inlägg m.m. i god tid. I vanliga fall är den här processen betydligt intensivare och stressigare. När jag läser gör jag oftast det i 60-90 minutersintervall, tar paus, gör något annat, äter. Skrivprocessen ser oftast ut så här. Formulerar mycket $\mathrm{i}$ huvudet medan jag läser och gör annat innan jag skriver.

I (II) beskrev Maria hur hon skriver sina "centrala slutsatser" dvs. den individuella sammanfattningen av dialogen. Hon beskrev också hur hon arbetar "i sitt huvud", innan hon börjar skriva en text.

I loggboken (7) beskriver hon hur hon läst, ätit lunch, läst igen, funderat kring fortsatta studier och sedan återgått till att skriva på sin lärandedialog. Vid en jämförelse med datorns logg (fig. 2) syns också att hon med vissa undantag arbetat i ungefär den ordningen.

Datorloggen visar att Maria inledde eftermiddagens arbete vid datorn (fig. 2) med att besöka Handelsanställdas förbund och söka efter framtida utbildningar. Sedan gick hon över till att logga in på lärplattformen och söka sig fram till sidan som heter "Uppgifter". Hon besökte sedan BRÅ:s hemsida och läste en text om brottsförebyggande åtgärder för att sedan gå tillbaka till lärplattformen och uppgiften. 


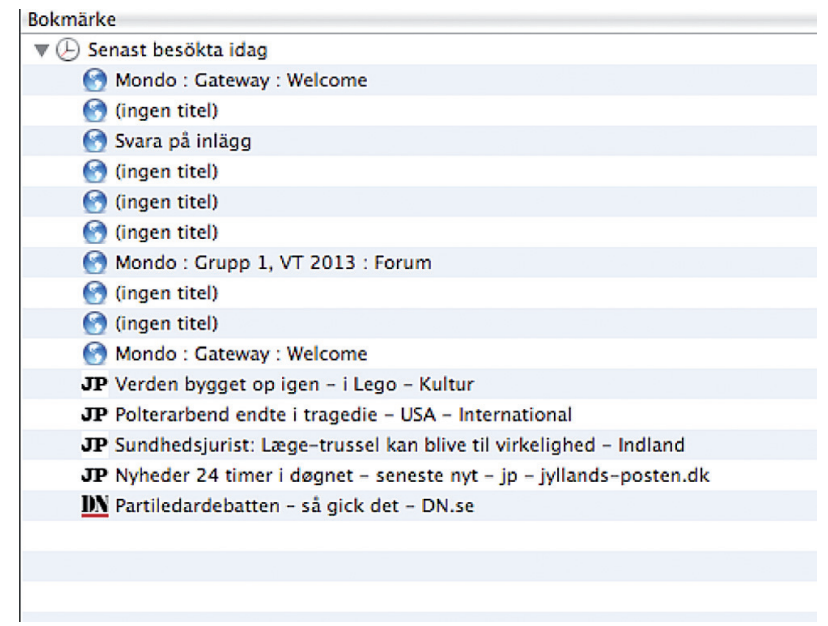

Fig. 2. Marias datorlogg

Närstudien av Marias arbete visar att det sker växling mellan läsande och skrivande samt växling mellan kursarbete och andra aktiviteter vid datorn. Maria visar också en arbetsgång som frångår kursdesignen och specifika instruktioner $(2,3)$, vad gäller skrivande av inlägg och responsgivande till andra. Maria väljer att skriva två inlägg parallellt, publicera det ena och ha det andra i beredskap tills andra kursdeltagare har fyllt på dialogen. Då reviderar hon sitt inlägg så att det ska passa som svar på någon annans inlägg, och publicerar det.

En sådan lösning på uppgiften talar mot att lärandedialogen kan ses som ett samtal där inläggen fungerar som repliker i en dialog. Det kan heller inte utifrån Marias beskrivning tolkas som att lärandedialogen är en aktivitet av samarbetsskrivande. Här har Maria i stället förberett vad hon vill ha sagt och väntar in de andras bidrag så att hon själv kan publicera och bli klar. Maria nämner inte själv att hon använt sig av lärarrespons på tidigare uppgifter i arbetet med denna dialog. Hon har i stället arbetat relativt självständigt med sina texter. Dessa stöttningsresurser har Maria den här gången inte tagit tillvara.

\section{Diskussion}

Vi har kunnat jämföra kursdesign, instruktioner och lärarresponser å ena sidan, och ett mindre antal kursdeltagares arbete med lärandedialog 4.I å den andra. Undersökningen har fokuserat på det för genrepedagogiken centrala begreppet stöttning (Martin \& Rose 20I2).

Kursdesignen erbjuder stöttning i form av de redskap eller funktioner som finns tillgängliga för studenternas skrivande och samarbete. Lärarna erbjuder en rad stöttningsresurser som tydliggör kraven på uppgiften, specificerar vad som faktiskt ska göras, och (i sin respons) poängterar vilka aktiviteter som är önskvärda i den diskussion studenterna fört. Lärarna erbjuder också stöttning i form av stödtexter om dels akademiskt skrivande, dels om hur skrivande i lärplattformen kan upplevas. Hur studenterna sedan gjort är olika för olika individer - några har följt lärarnas instruktioner relativt nära, medan andra (exempelvis informanten Maria) delvis följt instruktionen, delvis skapat en egen ordning för arbetet. Närstudiens Maria la dessutom upp sitt arbete på olika sätt vid olika tillfällen, och använde därmed kursens stöd olika. Det framgick dock inte av materialet att studenterna tog hjälp av den mer specifika stöttningen i sitt fortsatta skrivande på kursen. 


\section{S. Hållsten}

Artikelns diskussion kommer därför att fokusera på vilka delar av kursen som redan nu kan sägas ha ett genrepedagogiskt upplägg och vilka delar som skulle kunna förstärkas. Den diskuterar också hur stöttningen kan betraktas som allmän eller specifik - kan den sägas vara specifik för akademiskt skrivande, kriminologistudierna eller just för arbete i den här lärplattformen?

Ett första moment i den genrepedagogiska modellen är att gemensamt bygga fältet vad gäller texter, innehållsliga teman och perspektiv på kunskapsinnehållet. För nybörjarstudenten är det inte säkert att texter som ska skrivas inom utbildningen är bekanta vad gäller genre och funktion. Studenterna på kriminologikursen förväntades läsa läroböcker och forskningslitteratur parallellt med rapporter om exempelvis brottsstatistik, och sedan skriva texter med typiska akademiska krav (referera till litteratur på ett konventionellt sätt, förhålla sig till tidigare forskning och använda ämnets begrepp och teori). Vad är i så fall en lärandedialog för text?

Lärarna specificerade visserligen hur lärandedialogen skulle skrivas, när den skulle publiceras och i vilka skeden det gavs respons på texterna. Man var också tydlig med vad som skulle göras i texterna (resonera, redogöra för slutsatser, reflektera etc. Explicitgörandet av verbhandlingar kan naturligtvis ses som en generell stöttning inom en akademisk kontext, men är samtidigt ett specifikt inslag inom genrepedagogiken. Däremot aktualiserades aldrig vad just lärandedialogen utgjorde för en genre i ett kriminologiskt eller allmänt utbildningssammanhang. Var texten ett första utkast till en forskningsartikel, eller hade den skriftliga diskussionen snarast en kunskapsutvecklande, reflekterande funktion (jfr Kindeberg 2008)? Eller skulle lärandedialogen betraktas som en lokal genre skapad just inom den aktuella kursen? Man dekonstruerade alltså inte en tidigare lärandedialog för att på så sätt erbjuda studenterna redskap i form av kunskaper om själva genren.

Ett annat avsteg från den genrepedagogiska modellen var också avsaknaden av stöttning av ett gemensamt skrivande. Studenterna kunde visserligen läsa en allmän text om eventuella svårigheter med att skriva på ett digitalt forum, vilket kanske kan ses som en generell stötting av en typ av gemensamt skrivande. De fick dock inte något specifikt stöd för att skriva just lärandedialogerna. I stället fick de veta i efterhand, via responsen, om de diskuterat på ett för ämnet rätt sätt. Lärarnas respons stöttade såväl lingvistiskt och innehållsligt, men inte med fokus på det gemensamma skrivandet. Responsen kunde användas i arbetet med en nästföljande lärandedialog, men den var inte integrerad i det aktuella skrivandet eller byggt på en gemensam textdiskussion.

Sammantaget kan sägas att flera moment av stöttning fanns, men de tre genrepedagogiska stegen före det individuella skrivandet var inte särskilt framträdande i kursdesignen. Stöttningen var därmed inte genrepedagogiskt specifik. Däremot kan lärarresponsen ses som specifik stöttning vad gäller ämnets och uppgiftens innehåll. Ett exempel på specifik stöttning av annat slag var den inledande uppgiften som enbart syftade till att läsa sig det digitala redskapet, för att sedan kunna delta i kursen och arbeta med kommande uppgifter. Uppgiften uppmärksammade själva teknikanvändningen för just den här lärplattformen (Hållsten 2013).

Den specifikt genrepedagogiska stöttningen skulle dock kunna förstärkas, både vad gäller designen av lärplattformen och den stöttning lärarna gav: Inledningsvis skulle kursen kunna designas med kollaborativa brainstorm-övningar (Hort, Knutsson \& Blåsjö 2016) för att fullfölja genrepedagogikens första steg "building field" eller bygga ett gemensamt kunskapsfält. Man skulle också kunna synliggöra de olika texterna i termer av genrer. Ett sätt att stötta genom designen skulle kunna vara att stärka den beskrivning av lärandedialogen som redan fanns, med verktyg som föreslås av Hort, Knutsson och Blåsjö (20I6). Om kursens skriftliga uppgifter standardiserades mer så att det fanns möjlighet att beskriva dem i termer av basgenrer, med genresteg, skulle detta kunna fungera som färdiga s.k. promter (Hort, Knutsson \& Blåsjö 20I6:Io, Tsai \& Tsai 20I4:3-4), 
användbara för studenterna att strukturera sin egen text i. Man skulle också kunna konstruera mönstertexter där olika genresteg markerades som studenterna kunde använda när de skrev själva, och på det sättet bygga upp en textkorpus för det specifika akademiska fältet. Det skulle vara ett sätt där designen vägledde användaren pedagogiskt genom kursens skrivande. Slutligen skulle uppgiften lärandedialog kunna formuleras som en typ av samskrivande, med hemtentamen som måltext. På så sätt skulle kursdesignen ha tydliga genrepedagogiska moment, med möjligheter till mer specifik stöttning både av läraren i form av instruktionstexter och återkoppling på arbetet, och själva designen av kursen där av plattformens olika redskap användes pedagogiskt medvetet.

\section{Kan digitala diskussioner liknas vid samtal?}

Den analyserade kursen handlade om enbart skriftligt kommunikation: Förutsättningen för att designa kursen genrepedagogiskt är alltså att den skriftliga diskussionen kan liknas vid det muntliga samtalet. Avslutningsvis vill jag därför kort diskutera på vilket sätt en skriftlig ämnesinriktad diskussion går att jämföra med ett samtal.

Tidigare forskning har uppmärksammat chatt, sms och olika synkrona diskussionsfora såsom icke-traditionella skriftliga medier med särdrag som har likheter med tal och samtal. Det kan gälla talspråkslik turtagning, förstärkningsord, omedelbar återkoppling etc. (Androutsopoulos 20I4, Hård af Segerstad \& Hashemi 2005). Det handlar alltså om företeelser där skriften liknar talet på olika sätt.

Det omvända, att tal påverkas av skrift, kan också ses som relevant för diskussionen. En systemisk-funktionell undersökning av ett längre samtal där skriftspråkliga drag uppmärksammas och relateras till samtalets olika delinnehåll är Hallidays analys av betygsnämndens diskussion av en avhandling (Halliday 1994). Halliday iakttar hur deltagarnas grammatik ändras beroende på graden av ämnesinriktning i de olika samtalsbidragen, och resonerar hur kontext och ideationellt innehåll påverkar den textuella funktionen såväl som den interpersonella. När deltagarna talade om mer privata topiker och därmed intog en mer personlig roll i samtalet, användes en mer talspråksnära grammatik, medan när deltagarna gav ämnesspecifika samtalsbidrag intogs en mer professionell roll och användes en mer skriftspråksnära grammatik (Halliday 1994:24Iff).

Nyroos (20I2) har undersökt hur deltagare i bland annat det akademiska handledarsamtalet gemensamt konstruerar "institutionella agendor" (Nyroos 20I2:68). I samtalet socialiserar läraren in studenter till hur man ska förhålla sig till det övergripande temat i stället för att avhandla exempelvis praktiska detaljer kring ett uppsatsarbete. Deltagarna uppvisar också strävan att använda korrekta ord och begrepp och efterfrågar specifika ämnesrelaterade termer (Nyroos 2012:70). Läraren ska socialisera in studenterna i den verksamhet ett akademiskt samtal utgör genom att anta ett akademiskt perspektiv där läraren både ska bejaka studenternas frågor och träna dem i att ställa "rätt" slags frågor: "The teacher invokes an 'academic' perspective that pays less attention to specific students' projects, and focuses rather on an abstract discussion regarding theoretical dilemmas. His expansion of the sequence thus contributes to the interactional work of 'doing teaching' based on student questions raised in the tutorial activity" (Nyroos 20I2:50).

Dessa två undersökningar kan relateras till den skriftliga dialogen på lärplattformen som liknar det akademiska samtalet, med talarordning och en innehållslig orientering mot kurslitteratur eller specifika ämnesrelaterade termer. Detta är något som syns i både instruktioner $(2,3)$ och lärarresponsen (4). Nyroos visar också hur läraren stöttar denna samtalsform i syfte att skola in studenter i den akademiska genren seminarium. Med detta i åtanke kan den skriftliga dialogen å sin sida ses 
som en träning inför ett muntligt seminarium och därmed vara något som kan ingå i de genrepedagogiska momenten. Det skriftliga mediet har en inbyggd fördröjning i replikskiftena och möjliggör ett långsammare tempo (Coffin \& Hewings 2005). Eventuellt inbjuder det till mer planering av replikerna, vilket till och med skulle kunna ses som en fördel, just när det gäller träning i den akademiska seminariekulturen, där deltagarna förväntas följa talarordning, inte tala i mun på varandra och behålla sakfokus.

\section{Slutord}

Artikeln har diskuterat möjligheterna till ett genrepedagogisk design av en distanskurs på universitetsnivå. Fokus har legat på stöttning. Undersökningen visar att studenterna på distanskursen erbjuds vissa stöttningsresurser och att de både använt och inte använt de erbjudna resurserna. Undersökningen har också pekat på vad som inte erbjudits, exempelvis explicitgörande av vilken text som är målet för skrivandet. Sammantaget ska sägas att genrepedagogikens steg skulle kunna tillämpas i en kursdesign men att det i så fall skulle behövas ett genomtänkt pedagogiskt helhetsgrepp.

Vår kursplanering och lärarinsats tas förstås till vara på olika sätt av olika studenter. Vi kan aldrig få garantier för att våra studenter gör som vi har tänkt, vare sig på en traditionell kurs eller en kurs i ett digitalt medium. Det är en pedagogisk utmaning att använda en digital lärplattform så att den stöttar studenternas lärande och inte bara fungerar som ett administrativt redskap.

Att ha en samlande plats för all kursinformation och kommunikationen mellan studenter och lärare är naturligtvis värdefullt, men de lärplattformar som används i högre utbildning erbjuder även pedagogiska redskap för skrivande och lärande. Ett steg i den riktningen skulle kunna vara att utnyttja den potential lärplattformen har för stöttning av studenters skriv- och kunskapsutveckling genom att använda till exempel ett genrepedagogiskt arbetssätt.

\section{FÖRFATTARPRESENTATION}

Stina Hållsten är lektor i svenska vid Södertörns högskola, med erfarenhet av undervisning på ämneslärarprogrammet och forskning om praxisnära skrivande, både i yrkeslivet och inom högre utbildning. Hon har bland annat forskat om digitala lärplattformar och studenters skrivande. Hon är också medförfattare till (Schött et al.) Studentens skrivhandbok.

\section{REFERENSER}

Androutsopoulos, J. (20I4). Moments of sharing: Entextualization and linguistic repertoires in social networking. Journal of Pragmatics, 73, 4-18.

Ask, S. (2005). Tillgång till framgång: lärare och studenter om stadieövergången till högre utbildning. Lic.-avh. Växjö : Växjö universitet.

Bergman, L., \& Olsson Jers. C. (20I4). Vilken väg tar den kritiska granskningen? Studenter i samtal om en vetenskaplig artikel. Högre utbildning, 4(I), 35-47.

Blåsjö, M. (2004). Studenters skrivande i två kunskapsbyggande miljöer. Almqvist \& Wiksell International, Stockholm.

Blåsjö, M., Hållsten, S., Karlström, P., Knutsson, O. \& Cerratto Pargman, C. (20I4). Att skriva för att lära i digitala miljöer. Resultatdialog 20I4. Stockholm: Vetenskapsrådet.

Blåsjö, M., Knutsson, O. \& Cerratto Pargman, T. (20I2). Exploring the Design Space of Genre Pedagogy and Virtual Learning Environments. Designs for Learning 20I2: 3rd International Conference Exploring Learning Environments. Conference Proceedings. Paper presented at Designs for Learning 20I2, 25-27 April, Copenhagen, Denmark 20I2. 75-77. 
Brown, M. G. (2016). Blended instructional practice: A review of the empirical literature on instructors adoption and use of online tools in face-to-face teaching. Internet and Higher Education, 3I, I-IO.

Christie, F. \& Unsworth, L. (2005). Developing dimensions of an educational linguistics. Webster, J., Matthiesen, C. \& Hasan, R. (reds.) Continuing discourse om language: A functional perspective. London: Equinox.

Coffin, C. \& Hewings. A. (2005). Engaging electronically. Using CMC to develop students' argumentation skills in Higher Education. Language and Education, I9(I), 32-49.

Ekholm, D. (20I2). Handledning av examensarbeten som lärande i the zone of proximal development. Högre utbildning, 2(2), 67-78.

Flowerdew, John. (2002). Ethnographically inspired approaches to the study of academic discourse. I: J. Flowerdew (red.), Academic discourse. (pp. 237-252). Harlow: Longman.

Fryer, L. K. \& Bovee H. N. (20I6). Supporting students' motivation for e-learning: Teachers matter on and offline. Internet and Higher Education, 30, 2I-29.

Gibbons, P. (2006). Stärk språket, stärk lärandet : språk- och kunskapsutvecklande arbetssätt för och med andraspråkselever $i$ klassrummet. Uppsala: Hallgren \& Fallgren.

af Geijerstam, Å. (2006). Att skriva i naturorienterande ämnen i skolan. (Acta Universitatis Upsaliensis, Studia Linguistica Upsaliensia 2) Uppsala:. Institutionen för lingvistik och filologi, Uppsala universitet.

Halliday, M. A. K. (1978). Language as social semiotic. The social interpretation of language and meaning. London: Arnold.

Halliday, M. A. K. (1994). So you say 'pass' ... thank you three muchly. I: Allen D. Grimshaw (ed.), What's going on here: complementary studies of professional talk. Norwood, N.J.: Ablex. Omtryckt i.

Halliday, M. A. K. (2002). Linguistic Studies of Text and Discourse, I68-192.

Halliday, M. A. K. \& Matthiessen, Christian M.I.M. (2004). An introduction to functional grammar. 3 uppl. Reviderad av Christian M.I.M. Matthiessen. London: Arnold.

Holmberg, P. (20Io). Text, språk och lärande. Introduktion till genrepedagogik. I M. Olofsson (red.) Genrer och funktionellt språk i teori och praktik. (S. 53-72). Stockholm: Stockholms universitets förlag.

Holmberg, P. (2013). Att skriva förklarande text. Text som deltagare i praktiker och aktiviteter. I S. Hållsten, H. S. Rehnberg \& D. Wojhan (red.) Text, kontext och betydelse. Sex nordiska studier $i$ systemisk-funktionell lingvistik. Text- och samtalsstudier från Södertörns högskola. 2. (S. 53-72.) Huddinge: Södertörns högskola.

Holmberg, P. \& Wirdenäs, K. (20IO) Skrivpedagogik i praktiken Textkedjor, textsamtal och texttypologier i tre svensklärares klassrum. Språk \& Stil 20, I05-I3I.

Hort, S., Knutsson, O. \& Blåsjö, M. (20I6). Genre pedagogy for digital learning environments - Design patterns for dialogues about texts. I A-M. Nortvig, B. H. Sørensen, M. Misfeldt, R. Ørngreen, B. B. Allsopp, B. Henningsen, \& H. Hautopp (red.) (2016). Proceedings of the 5 th International Conference on Designs for Learning. (Open Access udg.) Aalborg: Aalborg Universitetsforlag.

Hyland, K. (2004). Disciplinary Discourse. Social Interactions in Academic writing. Michigan: The University of Michigan Press.

Hållsten, S. (20I3). När vardagen blir vetenskap. Konkret och abstrakt i kriminologitexter. I: S. Hållsten, H. S. Rehnberg \& D. Wojhan (red.) Text, kontext och betydelse. Sex nordiska studier i systemiskfunktionell lingvistik. Text- och samtalsstudier från Södertörns högskola. 2. (S. 89-106.) Huddinge: Södertörns högskola.

Hård af Segerstad, Y. \& Sofkova Hashemi, S. (2005). Skrivandet, nya media och skrivstöd hos grundskoleelever. Tidskrift för lärarutbildning och forskning, I-2, II9-I34.

Kindeberg, T. (2008). Forskarutbildningsseminariet som muntlig arena för lärande. Rhetorica Scandinavica. Tidskrift för skandinavisk retorikforskning 45, 49-67.

Knutsson, O., Blåsjö, M., Hållsten S. \& Karlström, P. (20I2). Identifying Different registers of digital literacy in virtual learning environments. The Internet and Higher Education, I5 (4), 237-246. 
Macken-Horarik, M. (I996). Literacy and learning across the curriculum. I: R. Hasan \& G. Williams, (red.) Literacy in society. London: Longman.

Martin, J. R. \& Rose, D. (2008). Genre relations. Mapping culture. London: Equinox.

Martin, J. R. \& Rose, D. (20I2). Learning to Write/Reading to learn. London: Equinox.

Mörndahl, M. (20II). Överföring, interaktion eller samarbete? I S. Hrastinski (red.), Mer om nätbaserad utbildning - fördjupning och exempel. (S. 3-70). Lund: Studentlitteratur.

Nygård, P. Larson. (2OII). Biologiämnets texter. Text, språk och lärande i en språkligt heterogen gymnasieklass. Malmö: Malmö högskola.

Nyroos, L. (2012). The Social Organization of Institutional Norms: Interactional Management of Knowledge, Entitilement and Stance. Skrifter utgivna av Institutionen för nordiska språk, 87. Uppsala: Uppsala universitet.

Olofsson, M. (20I0). Genrepedagogik med lärare i gymnasieskolan och vuxenutbildningen. Symposium 2009. I: M. Olofsson (red.) Genrer och funktionellt språk $i$ teori och praktik. (S. 247-269) Stockholm: Stockholms universitets förlag.

Pink S., Horst H., Postill J., Hjorth L., Lewis T. \& Tacchi J. (2015). Digital ethnography. Principles and Practice. New York: Sage.

Rienecker, L. \& Stray Jörgensen, P. (2003). The genre in focus, not the writer: Using model examples in large-class workshops. I: L. Björk, G. Bräuer, L. Rienecker, \& P. Stray Jörgensen, Peter (red.) Studies in Writing I2. Teaching Academic Writing in European Higher Education, 59-74.

White, B. (2009). Teaching language across the secondary curriculum using a teaching and learning cycle. I: M. Olofsson (red.) Genrer och funktionellt språk i teori och praktik. (S. 52-78) Stockholm: Stockholms universitets förlag.

Winters, N. \& Mor, Y. (2009). Dealing with abstraction: Case study generalization as a method for eliciting design patterns. Computers in Human Behaviour, 25(5), I079-1088.

Vygotskij, L. (200I). Tänkande och språk. Göteborg: Daidalos.

Tsai, P-S. \& Tsai, C-C. (20I4) College students' skills of online argumentation: The role of scaffolding and their conceptions. The Internet and Higher Education 2I, I-8. 